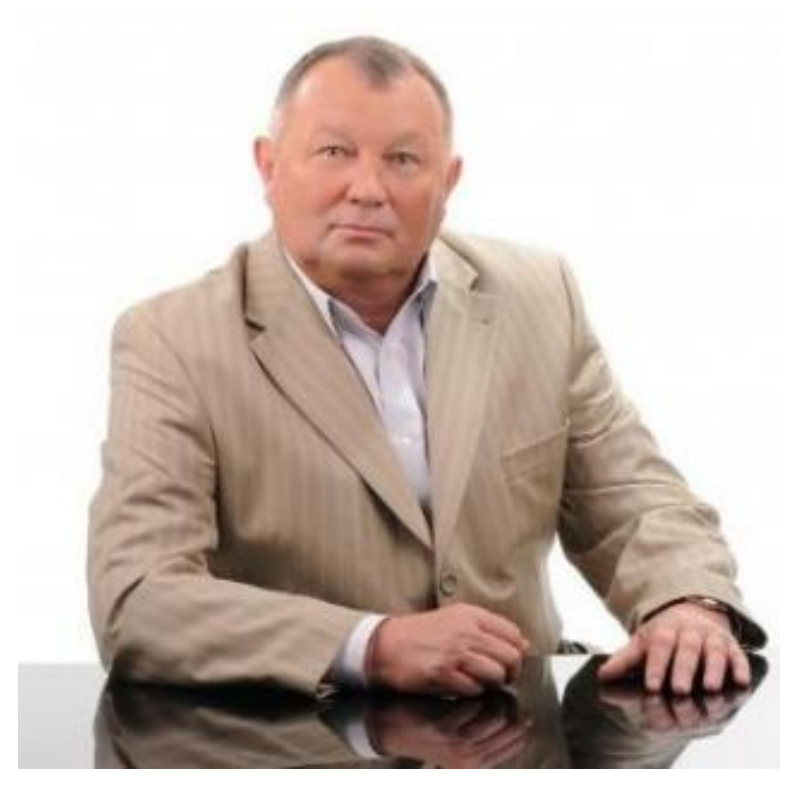

\author{
APOSTOL \\ Mykhailo V., \\ Doctor of Historical Sciences, \\ Senior Researcher of the Science Study \\ Sector of the Institute of History of \\ Agrarian Science, Education and \\ Technique of the National Scientific \\ Agricultural Library NAAS \\ (Kyiv, Ukraine) \\ apostolmv_1961@ukr.net
}

\title{
PROFESSOR V.P. USTYANTSEV'S (1875-1935) ACTIVITIES IN THE CONTEXT OF THE FORMATION OF AGRICULTURAL EXPERIMENTAL WORK AND HIGHER PROFESSIONAL EDUCATION IN UKRAINE
}

The author goal is to highlight the main milestones in the life and creative path of a talented scientist in the field of animal husbandry, the founder of agricultural research work and higher professional education in Ukraine, Professor V.P. Ustyantsev. The research methodology is based on the predominant use of historical and scientific analysis, as well as the biographical method as a means of reconstructing the intellectual biography of the scientist. The source base of the research covers a wide range of published and unpublished materials, it is based on archival documents and V.P. Ustyantsev's scientific papers. The scientific novelty of the publication lies in the substantiation of the scientist's contribution to the development of the physiology of feeding farm animals, the development of the problems of ensiling local forages its influence on the productivity of livestock. It is summarized V.P. Ustyantsev's contribution in the development of a program and methodology for an expeditionary survey of animal husbandry in the Kiev province, the introduction of the first state herd books as the basis for the formation of breeding in Ukraine. It is considered the development of the theory of ontogenesis, the foundations of the mineral and protein nutrition of farm animals as priority direction of his scientific heritage. The role of the scientist in the organization and activities of specialized zootechnical cathedras at the Novo-Alexandria Institute of Agriculture and Forestry, Kiev Polytechnic, Kiev Agricultural and Kiev Veterinary \& Zootechnical institutes, as well as at the Moscow Institute of Horse Breeding is shown. V.P. Ustyantsev substantiated the need to introduce the course "Physiological foundations of farm animal feeding" in the vocational education program. The achievements of the scientist in the formation of the Kiev, Nosov and Polessia 
regional agricultural experimental stations, the All-Union Institute of Animal Husbandry are considered.

Key words: animal science, zootechnical education, agricultural research work, feeding of farm animals, V.P. Ustyantsev.

\section{ДІЯЛЬНІСТЬ ПРОФЕСОРА В.П. УСТЬЯНЦЕВА (1875-1935) В КОНТЕКСТІ СТАНОВЛЕННЯ СІЛЬСЬКОГОСПОДАРСЬКОЇ ДОСЛІДНОЇ СПРАВИ І ВИЩОЇ ПРОФЕСІЙНОЇ ОСВІТИ В УКРАЇНІ}

Автором поставлена мета висвітлити основні віхи життєвого і творчого шляху талановитого вченого в галузі тваринництва, фундатора сільськогосподарської дослідної справи і вищої професійної освіти в Украӥні, професора В.П. Устьянщева. Методологія дослідження трунтується на переважному використанні історико-наукового аналізу, а також біографічного метода як засобу реконструкиіі інтелектуальної біографії вченого. Джерельна база дослідження охоплюе широке коло опублікованих $i$ неопублікованих матеріалів, ї̈ основу складають архівні документи і наукові праці В.П. Устьянщева. Наукова новизна публікації полягає в обтрунтуванні внеску вченого в становлення фізіології годівлі сільськогосподарських тварин, розробиі проблем силосування місиевих кормів $і$ їх виливу на продуктивність худоби. Узагальнено внесок В.П. Устьяниева в розробку програми $і$ методики експедиційного обстеження тваринництва Київської губернії, введення периих державних племінних книг як основи становлення племінної справи в Украӥні. Як пріоритетні напрями наукових розробок вченого, розглядали також розвиток теорії онтогенезу, основ мінерального $i$ білкового живлення сільськогосподарських тварин. Показана роль ученого в організащії і діяльності спеціалізованих зоотехнічних кафедр при Ново-Олександрійському інституті сільського господарства і лісівництва, Київському політехнічному, Київському сільськогосподарському і Київському ветеринарно-зоотехнічному інститутах, а також при Московському інституті конярства. В.П. Устьянцев обтрунтував необхідність введення курсу «Фізіологічні основи годівлі сільськогосподарських тварин» в програму професійної освіти. Розглянуті досягнення вченого в становленні Київської, Носівської і Поліської крайових сільськогосподарських дослідних станцій, Всесоюзного інституту тваринництва.

Ключові слова: зоотехнічна наука, зоотехнічна освіта, сільськогосподарська дослідна справа, годівля сільськогосподарських тварин, В.П. Устьяниев.

Introduction. Recent decades have been marked by a growing interest in the biographical method in the study of the history of agricultural science. Reconstruction of intellectual biographies is based on the study of personalities, in this case scientists, in the context of their relationship with society, aimed at 
reproducing their life programs, social and intellectual space. Intellectual biography studies in the agricultural sector are based on the idea of the individual as a specific model of creation of sectoral scientific thought, which should include: 1) a factual description of his life; 2) personal approach to the development of the scientific process; 3) subject approach; 4) cultural principles (connection with the general historical process, its influence on the formation of scientific priorities), etc.

In the formation and development of zootechnical science and higher professional education in Ukraine, the organization of the first experimental institutions in animal husbandry, a significant contribution was made by a talented scientist and teacher, Professor V.P. Ustyantsev. His name is associated with the development of theoretical and methodological foundations of the physiology of feeding and individual development of farm animals, improvement of the expeditionary method of inspection of domestic livestock and formalization of the principles of breeding work. Less well known in scientific circles is his experimental work on ensiling, which contributed to the introduction of an effective method of local feed preserving and, as a result, increased the profitability of the livestock industry.

The some aspects of scientific and professional activities of V.P. Ustyantsev have found a reflection in the articles by N.M. Zubets, V.A. Verhunov [9, 6], in publications by I.S. Borodai et al. [3, 4, 8]. However, the authors did not consider Professor V.P. Ustyantsev's scientific achievements in the field of feeding farm animals, his developments in the field of breeding work systematically. The scientist's contribution to the formation of the Novo-Alexandria Institute of Agriculture and Forestry, as well as to the organization of the Kiev Veterinary \& Zootechnical Institute has partially considered in publications dedicated to the anniversary dates of V.V. Dokuchaev's Kharkiv National Agrarian Institute and the National Agrarian University [10, 7]. Some fragments of V.P. Ustyantsev's activities in the Kiev Experimental Station of Animal Husbandry "Terezine" have described [8]. 
The purpose of this research is to outline the main milestones in the scientific activities of Professor V.P. Ustyantsev as a leading scientist in the field of feeding farm animals, organizer of experimental work and pedigree business in animal husbandry, as well as higher zootechnical education in Ukraine, to systematize his scientific heritage.

Research methods. The theoretical and methodological basis of the research is the principles of historicism, scientific character and consistency in the coverage of factual material, the complex use of general scientific, structural-functional, interdisciplinary methods. Traditional general scientific methods such as synthesis, analysis, systematization and classification were used to demarcate the object and subject of research, formulate its goals and objectives, conclusions and generalizations, and structure the presented material. The biographical method was widely used as a basis for the reconstruction of the intellectual portrait of Professor V.P. Ustyantsev, his professional activities. The article is based on the use of the modern categorical and conceptual apparatus of the history of science and technique, takes into account the problems of the formation of agrarian biography study and bibliography in Ukraine, as well as the interdisciplinary nature of this research. Conducting our research, we used the scientific approaches of researchers of the history of formation and development of physiology and hygiene of farm animals as a theoretical and methodological basis $[22,1]$.

The use of the traditional and modern research methods made it possible to efficiently process the source base, represented primarily by archival materials and scientific papers, as well as by leading periodicals.

Results and discussion. Vasily Ustyantsev was born on January 25, 1875 in Vyatka (Russian Empire) into a large family of a retired soldier. He graduated from the Vyatka Real School, entered the Novo-Alexandria Institute of Agriculture and Forestry, which he successfully graduated in 1898. According to the decision of the Council of the Institute, he was left as an assistant at the Cathedra of General Animal Science, headed by recognized specialist in the development of norms and rations for 
farm animal feeding, Professor I.I. Kalugin. Close cooperation with the scientist reflected on the formation of his further scientific priorities [12, p. 3].

In 1899, the first scientific work of V.P. Ustyantseva "On the assimilation of crude protein in bran" was publicated. From December 13 to 19, 1901, he took part in the work of the 1st Congress of agricultural experimental workers in St. Petersburg. The formation of the scientific priorities of the researcher was greatly influenced by foreign scientific trips in 1900, 1901, 1904, 1906, during which he studied the basics of the physiology of farm animal feeding in the most progressive scientific centers of Europe. As the analysis showed, the prerequisite for the formation of the science of farm animal feeding in Russian Empire was the developments of foreign and domestic scientists in the fields of physics, chemistry, physiology, biology, biochemistry and other sciences, which formed its theoretical and methodological basis [2]. Like previous researchers of V.P. Ustyantsev's scientific activity, we share the opinion that training in 1904 in Germany at the Physiological Institute under Professor Zuntz, where he carried out a number of important scientific studies on the physiology of feeding, was especially productive $[9,6]$. As he himself testified, in this laboratory for the first time in world practice attention was drawn to "the fermentation processes in the alimentary tract, which were especially intense in ruminants and with which significant energy losses were certainly associated, for example, the heat of fermentation, which cannot be used for the productive activity of the animal and therefore reduces digestibility of food". After his return to homeland, the scientist was actively continuing his experiments on studying the processes of food digestion. Researching the phenomenon of fermentation in the gastrointestinal tract of farm animals, he pays special attention to the digestibility of feed that was previously fermented [12, p. 4].

In 1906, he defended his master's thesis "On the nutrition of herbivorous animals with fiber and roughage". In the experimental part of his research, for the first time in the domestic zootechnics, he applied the method of respiratory experience. In the same year, for the first time in the country, he began to teach the course "Physiological foundations of farm animal feeding" at the Novo-Alexandria Institute 
of Agriculture and Forestry (now the V.V. Dokuchaev's Kharkiv National Agrarian Institute). Simultaneously he teaches general and special zootechnics at the St. Petersburg agricultural courses [13, p. 2].

As the analysis showed, during this period, domestic scientists had a priority in solving some problems of farm animal feeding. In our opinion, especially important were the M. Chyrvinskyi's developments, who in 1882 proved the possibility of formation of fat from carbohydrates, that contributed to the improvement of systems for assessing the productive effect of feed. Another significant achievement of the scientist was the substantiation of the influence of the level of feeding on the growth and development of animals. It should be noted that M. Chyrvinskyi was the first who raised the question of the need of farm animal feeding in Russia at the First Congress of Agricultural Experimental Affairs in 1901. No less important achievement of this period was the experimental establishment of direct and indirect participation of protein feed in the formation of fat in animal body by Ye. Bogdanov in 1903-1908. The scientist has shown that along with the overall nutritional value of the food, it is necessary to consider the protein and vitamin ones. He developed the doctrine of normalized feeding, taking into account the physiological state of animals, ecological and economic characteristics of the livestock sector of various natural and climatic zones of the country [2].

Since 1911, V.P. Ustyantsev lectured on special zootechnics at the Kiev Polytechnic Institute of Emperor Alexander II (now the National Technical University of Ukraine "Igor Sikorsky's Kiev Polytechnic Institute"). In 1912, he was appointed head of the Cathedra of Special Cattle Breeding, and a year later he was awarded the academic title of professor. In this multidisciplinary institution of higher education, he collaborates with such renowned scientists in the field of animal science as Professor N.P. Chirvinsky and A.S. Ivanov, which radically affected the direction of further scientific searches of V.P. Ustyantsev. During this period, he laid the foundation for a new scientific direction - the expeditionary survey of animal husbandry [12, p. 3]. In 1912, on behalf of the provincial administrations, he developed a program and methodology for an expeditionary survey of animal 
husbandry in the Kiev and Podolsk provinces. Since it was practically impossible to conduct such a large-scale survey at that time, he proposed a sample method. For this purpose, the scientist chose several settlements typical of the above-mentioned provinces.

Simultaneously with the peasant settlements, he surveyed the landowners' farms, which had numerous commodity and breeding herds. We have established that most of such farms V.P. Ustyantsev visited with the senior specialist of the Department of Agriculture L.I. Senchenko. Expeditionary work was started in early May and continued until the end of October 1913. The specificity of this expeditionary survey consisted in a detailed clarification of local natural-geographical and socio-economic conditions, study of its influence on the formation of economically useful qualities of livestock, determination of areas favorable for the development of animal husbandry. It should be noted that the expeditionary method, improved by V.P. Ustyantsev at the beginning of the twentieth century, has not lost its decisive importance at the present stage of development of animal husbandry, it is given considerable attention in the development of measures for the rational use and preservation of the gene pool of farm animals. Under these conditions, the main goal of the expeditionary survey is to establish the selection and genetic status of breeds with an integral assessment of their gene pool and to determine the prospects for breeding [14].

Contemporaneously with the new scientific searches of V.P. Ustyantsev continued to develop the physiological foundations of farm animal feeding. He took an active part in organizing the work of the stockyard, created at the Kiev Polytechnic Institute for practical training of students. He proved the feasibility of feeding to livestock a tree hay from branches of various breeds. In 1913, he took part in the work of the 1st All-Russian Agricultural Congress, which helded in Kiev on September 1-10. He made a report "Organization and some data of animal husbandry research in the Kiev province", in which he outlined specific measures for the development of the branch. The general meeting of the Kiev Society of Agriculture and Agricultural Industry elected him as its full member. He was also one of nineteen 
teachers of permanent agricultural courses organized by this society, and regularly lectured on animal husbandry [6].

V.P. Ustyantsev also took part in the work of the $1^{\text {st }}$ All-Ukrainian Agronomical \& Economic Congress, which took place on October 25, 1917 in Kiev. He made a report "Characteristics of groups of local cattle", in which he summarized the productive and pedigree qualities of the main domestic breeds. He supported to establish the first national authority for agricultural experimental business - the Ukrainian Regional Research Committee. According to V.A. Vergunov, after his second report "Cattle breeding areas within the Kiev and Podolsk provinces", the congress participants decided to convene a regional meeting of livestock specialists to prepare a plan for measures to improve cattle breeding in Ukraine and oblige the authorities to develop measures to preserve and develop the gene pool of local cattle breeds. After the opening in 1919 of the Section of Agriculture at the Commission for the Study of the Natural Forces of Ukraine of the Physics \& Mathematics Department of the Ukrainian Academy of Sciences, he became its member. He prepared a section on cattle breeding for the collection "Agriculture and Rural Industry of Ukraine" [6].

In 1920, V.P. Ustyantsev was elected Dean of the Agricultural Department of the Kiev Polytechnic Institute. In subsequent years, he actively participated in the reorganization and creation, according to order No. 141 of September 20, 1922, on its basis, the Kiev Agricultural and Kiev Veterinary \& Zootechnical Institutes [22, p. 5]. At the Zootechnical Faculty of the Kiev Veterinary \& Zootechnical Institute, which he headed, such special disciplines were taught: breeding and acclimatization, feed and feeding, exterior and physiology of farm animals, zoohygiene, pathological physiology, research in animal husbandry, milk production, dairy business, sheep breeding, big horned cattle, horse breeding and horse breeding, poultry farming, rabbit breeding, pig breeding, fish breeding, beekeeping, technology of livestock products. V.P. Ustyantsev taught breeding and acclimatization courses for farm animals, feed and feeding. In 1930, on the basis of the Kiev Veterinary \& Zootechnical Institute, the Kiev Zootechnical Institute was established, but already in 
1934 it was transformed into the Zootechnical Faculty of the Dnepropetrovsk Agricultural Institute [7].

At the Kiev Agricultural Institute in the summer of 1923 a Zootechnical Department with Cathedras of General and Special Zootechnics was opened. The following courses were taught: 1) parasitology; 2) meat knowledge; 3) state and public events for the massive improvement of animal husbandry; 4) experimental business with livestock breeding; 5) zoo hygiene. The course of animal physiology included the discipline - the exchange of matter, to the course of general zootechnics - the feeding and exterior of animals. The curriculum also included the special disciplines in the branches of animal husbandry, in particular, fish farming, beekeeping and poultry farming. In particular, as we noted in our previous publications, Professor V.P. Ustyantsev lectured general animal science and experimental work [5].

It should be noted, the successful educational process of this period was not facilitated by too frequent reorganization of higher educational institutions, changes in its subordination. So, according to the resolution of the Council of People's Commissars of the Ukrainian SSR dated July 12, 1930 "On the reorganization of higher educational institutions and higher technical educational institutions and its transfer to the jurisdiction of the corresponding people's commissariats" on the basis of the Kiev Agricultural Institute, a number of independent institutions were established. At the end of 1934, the Cathedra of Animal Science was restored to its structure. At the Cathedra general and special zootechnics, as well as physiology courses with anatomy of farm animals were taught.

Simultaneously with the teaching work of V.P. Ustyantsev performed an active scientific and organizational work. Since 1920, he was in charge of the research Cathedra of Zootechnics at the Administration of Scientific Institutions "Ukrnauka", as well as a scientific consultant for the variety-seed board of "Sovgospsakhar", a member of the All-Ukrainian Research Committee and the Scientific \& Consulting Council of the People's Commissariat of Agriculture of Ukraine. He took an active part in the work of the All-Ukrainian Agronomic Society. At the meeting on May 18, 
1923, he presented a report "Experience in the ensiling of beet tops". Together with Yu.Z. Uman, A.S. Ioffe, I.A. Shirokikh developed a program and plan for the survey of the German Red breed, which was carried out in 1923 at the initiative of the Livestock Dpartment of the People's Commissariat of Agriculture of Ukraine in the Odessa, Yekaterinoslav and Donetsk provinces. After the opening of the AllUkrainian Agronomic Society in 1920, he became a member of the council of its Kiev branch. He initiated and headed its Cattle Breeding Section, together with Professor H.I. Klassen, established an All-Ukrainian Society of Livestock Breeders. For this purpose, he joined in holding a special congress at the end of August 1923 to consider questions of the further development of animal husbandry. When discussing the issue at the section on its participation in the All-Russian Agricultural Exhibition in 1923, he made a report "Experience of ensiling beet tops".

After the founding in 1926 of the Permanent Commission of the All-Ukrainian Academy of Sciences for the study of the productive forces of Ukraine, he was elected a member of its plenum-presidium and is engaged in the activities of the Cattle Breeding Section together with Professor S.A. Ivanov. He took an active part in the work of the Scientific \& Consulting Council at the Collegium of the Ukrainian SSR People's Commissariat of Agriculture. So, at its I session, held on April 4-7, 1928, V.P. Ustyantsev made a presentation on the feed issue in Ukraine. He developed a detailed analysis of feed rations for livestock of peasant farms in all zones of Ukraine, both in absolute quantities and in starch equivalents. He pointed to the monotony and imbalance of local diets, the main share of which was roughage, mainly straw. According to the results of the analysis, unsatisfactory feeding was the main reason for the low payment for feed and due to the insufficient profitability of the cattle breeding industry [15].

V.P. Ustyantsev made significant efforts to establish a research work in animal husbandry. In particular, he was a scientific consultant for the Kiev, Nosov and Polesye regional agricultural research stations. The role of the scientist in the formation of the Kiev regional agricultural experimental station was especially significant. In the fall of 1921, he headed the Zootechnical Department formed in its 
structure. However, due to the lack of premises for livestock and the farm animals, the department could not immediately begin its work. In 1922, under the leadership of the scientist, the first experiments on ensiling fodder were carried out at the station, with the aim of finding out the expediency of this method of its harvesting in the conditions of small peasant farms. Silage was made from the tops of beets and turnips, winter vetch with rye, cabbage leaves, herbs, sedge bog grasses and root crops. It was carried out a number of experiments with corn silage.

We have substantiated in previous works that Professor V.P. Ustyantsev was a pioneer in organizing a scientific study of silage issues in Ukraine. He argued that this method has an advantage over drying, since it allows to save more valuable substances for animal nutrition [18]. Throughout his scientific activity, he continued to actively search for ways and methods of increasing the productive action of roughage, solving problems of metabolism in farm animals. The results of these experiments became known to the wide scientific community and were intensively introduced into production. He paid special attention to the study of local forages and its productive effect on the animal's body. He also studied the issues of summer cattle feeding and keeping [16].

In October 1926, the Zootechnics Department of the Kiev Regional Agricultural Experimental Station was transferred to the village Teryzino, Bila Tserkva district, which became the base not only for research work in all branches of animal husbandry, but also for providing animals with own concentrated, coarse, juicy and green feed. This year, a subdivision of cattle was formed on the initiative of V.P. Ustyantsev, in the formation of which he took an active part. Its activities, first of all, were aimed at improving the productive and pedigree qualities of the Simmental, White-Headed Ukrainian and Black-and-White breeds most widespread in this region [8].

V.P. Ustyantsev conducted a special examination of the White-Headed Ukrainian breed, which he considered as well adapted to breeding in Ukraine. He paid considerable attention to the formation of breed productive qualities, studied the effect of various feeding diets on its. This work, in addition to its great practical 
value, was also important for a methodological point of view, since it used the methods of a comprehensive survey of livestock. As a result, the pedigree book of White-Headed Ukrainian cattle was opened, and Professor V.P. Ustyantsev was appointed as its deputy chairman [5].

In August 1929, on the basis of the Zootechnical Department, an independent research institution was established - the Kiev Zootechnical Research Station "Terezino" (now M.V. Zubets' Institute of Animal Breeding and Genetics NAAS) in the structure of the People's Commissariat of Agriculture of Ukraine. To obtain the status of the leading regional scientific, methodological and coordination center in animal husbandry, a lot of efforts were made by Professor V.P. Ustyantsev [8].

Given V.P. Ustyantsev's authority in scientific circles, after organization the All-Union Institute of Animal Husbandry (now L.K. Ernst's All-Russian Research Institute of Animal Husbandry, Moscow) in 1930, he was invited to the post of Head of the Laboratory for Feeding and Metabolism of Farm Animals. In addition to conducting experimental work in the laboratory, he also supervised research work on feeding farm animals of the entire network of research zootechnical institutions that were part of V.I. Lenin's All-Union Academy of Agricultural Sciences. In particular, he headed a number of research works on the topic: the establishment of typical regional feed rations for dairy cows using local feed and maximum use of silage. During those years V.P. Ustyantsev also worked to establish a unified methodology for experiments on feeding farm animals. His book "Feeding Farm Animals", published in the second edition in 1933, was adopted as a textbook for all higher agricultural institutions in the country. In the same year, under his editorship, the collection "Methods of zootechnical research on feeding farm animals" was published [4].

It is important to note that at this stage, Professor V.P. Ustyantsev showed deep interest in studying the problems of ontogenesis of farm animals. He considered the organization of purposeful upbringing of young animals as the key to a qualitative improvement in domestic cattle breeding, in particular, an improvement in growth, live weight, exterior forms and in animal productivity. Together with 
S.V. Serapin he summarized all the experimental experience accumulated in the USSR and abroad in this direction and developed recommendations for rationalizing the methods of raising young cattle in the dairy direction of productivity [17].

Other subject developed by V.P. Ustyantsev's efforts were the foundations of the mineral nutrition of farm animals. He became one of the first scientists of the former Soviet Union who performed a series of experiments and initiated the study of the exchange of calcium and phosphorus in dairy cows and calves. He paid no less attention to the problem of protein nutrition of animals, the solution of which he saw possible due to the increase in the feed rations of legumes and concentrates. In the Laboratory of Feeding and Metabolism of Farm Animals, he carried out comprehensive research on 1) obtaining protein-enriched fodder yeast; 2) feeding animals with nitrogenous substances of non-protein origin as substitutes for part of the proteins in the diet; 3) the search for ways of more economical use of protein substances in feed $[19,21]$.

In 1934 V.P. Ustyantsev was also invited to the Moscow Institute of Horse Breeding, where he teaches courses on feeding and metabolism in horses. Under his leadership, the method for determining the digestibility of feed in horses was improved. Despite the overload of the main scientific research and pedagogical work, the scientist responded to all measures taken in the field of reconstruction of animal husbandry. So in 1933, as a member of the committee on crop rotations at the People's Commissariat for Agriculture of the USSR, he went to Ukraine, where he took an active part in the design of crop rotations, defending the interests of animal husbandry. V.P. Ustyantsev was also an active member of the All-Union Scientific, Engineering and Technical Society for Animal Breeding and the chairman of the Moscow Regional Bureau of this society, a permanent participant in various regional meetings of specialists, where he shared his longstanding experience and achievements in the field of feeding farm animals.

At 1935 V.P. Ustyantsev gave a positive assessment and took for approbation the method of determining the capacity of the forage base of a grassland economy, developed by an employee of the laboratory of feeding and metabolism of 
agricultural animals of the All-Union Institute of Animal Husbandry P.I. Krupsky. However, since the events unfolded in the 30s, associated with the tightening of the political press under the conditions of a totalitarian state and regular personnel cleansing at all its levels, the basic principles of the development of science democracy, independence from politics, were grossly violated. Soon P.I. Krupsky was recognized as the "public enemy", and V.P. Ustyantsev, without any reason, was sharply criticized for contributing to his "reactionary" activities [11]. All this seriously affected the scientist's health and he suddenly dies.

V.P. Ustyantsev's scientific heritage of has not lost its great practical importance in the modern conditions of the development of the livestock industry in Ukraine, when special attention is paid to the development of the physiology of feeding farm animals and breeding. Scientist have published more than 80 scientific papers, including the main ones: "Experiments on the ensiling of beet tops and its feeding to dairy cows" (1928), "The fodder issue in Ukraine" (1928), "Research work in feeding of the farm animals" (1929) , "Preparation for calving and preservation of offspring" (1933), "The effect of the addition of chalk and fish oil on mineral metabolism in calves" (1934), "Raising the calves" (1934), "Research work in the field of training and use of feed" (1934).

Conclusions. Thus, Professor V.P. Ustyantsev went in the history of domestic animal husbandry as a talented scientist in the physiology of feeding farm animals, an organizer of branch experimental work and higher professional education, a popularizer of the achievements of agricultural science. His priority in the development of a method of ensiling and studying the effect of silage on the productivity of livestock, approbation of the method of respiratory research was proved. The scientist contributed to the formation of pedigree business in Ukraine, having developed the first program of expeditionary research of animal husbandry, the basics of keeping herd books on the example of the Ukrainian White-Headed breed. The development of the theory of ontogenesis, the foundations of mineral and protein nutrition of farm animals were also considered as the defining directions of the scientific heritage of the scientist. V.P. Ustyantsev's contribution to the 
organization of higher zootechnical education, the first specialized educational structures in animal husbandry at the Novo-Alexandria Institute of Agriculture and Forestry, Kiev Polytechnic, Agricultural and Veterinary \& Zootechnical Institutes, and the Moscow Institute of Horse Breeding was justified. V.P. Ustyantsev read the first course "Physiological foundations of farm animal feeding » on the Ukrainian lands. No less significant contribution of the scientist to the development of experimental work in animal husbandry, in particular the leading sectoral research centers - the All-Union Institute of Animal Husbandry, as well as regional institutions - the Kiev, Nosovsk and Polessk regional agricultural experimental stations, was noted.

\section{Список використаних джерел та літератури}

1. Bey R.V. Development of hygiene of farm animals in Ukraine (the second half of the $19^{\text {th }}$ - early $21^{\text {th }}$ centuries). Relevant research of historical sciences : collective monograph. Lviv-Toruń: Liha-Pres, 2019. P. 31-48. DOI https://doi.org/10.36059/978-966-397-100-1/31-48.

2. Borodai I.S. Formation and development of the science of farm animal feeding (the second half of the $19^{\text {th }}$ - early $21^{\text {st }}$ centuries). Relevant research of historical sciences: collective monograph. Lviv-Toruń: Liha-Pres, 2019. P. 49-67. DOI https://doi.org/10.36059/978-966-397-100-1/49-67.

3. Бородай I. С. Устьянцев Василь Павлович. Iсторія Інституту розведення і генетики тварин у подіях, фактах, біографіях учених / наук. ред. К. В. Копилова. Бориспіль: Люксар, 2012. С. 316-317.

4. Бородай I. Розвиток зоотехнічної науки в Україні в контексті діяльності професора В. П. Устьянцева. Історія украӥнської науки на межі тисячоліть. Київ, 2009. Вип. 41. С. 28-35.

5. Бородай I. С. Теоретико-методологічні основи становлення та розвитку вітчизняної зоотехнічної науки : монографія / наук. ред. В. А. Вергунов. Вінниця, 2012. 416 с.

6. Вергунов В.А. Історія сільськогосподарської дослідної справи в Україні (До 100-річчя створення Національної академії наук України): у 3-х ч. Київ: Аграрна наука. 2018. Ч. 1: Творці та розбудовники (біографічні нариси). $604 \mathrm{c}$.

7. Діденко В. В. Нарис історії Національного аграрного університету (до сторіччя заснування). Київ : Аграрна наука, 1998. 175 с.

8. Зубець М. М., Бородай І. С. Київська дослідна станція тваринництва «Терезине»: історія, здобутки, вчені / наук. ред. В. А. Вергунов. Вінниця, 2011. 208 c. 
9. Зубець М. М. Учений-дослідник В. П. Устьянцев: його внесок у становлення зоотехнічної науки. Тваринництво України. № 4. 2011. С. 34-36.

10. Киричок P.I., Голікова О.М., Гриценко 3.I. Харківський національний аграрний університет ім. В. В. Докучаєва. 1816-2006. Харків, 2006. 367 с.

11. Нейман О.Ф., Завадовский Б.М., Азимов Г.И. Всесоюзный институт животноводства. Проблемы животноводства. 1935 №1-2. С. 11-20.

12. Особова справа В.П. Устьянцева // Державний архів м. Київ. Ф. 16. Оп. 465. Спр. 4820. 16 арк.

13. Особова справа В.П. Устьянцева // Центральний державний архів вищих органів влади і управління України. Ф. 166. Оп. 12. Спр. 7904.7 арк.

14. Устьянцев В.П. Материалы по обследованию животноводства в Киевской губернии. Очерк положения крестьянского животноводства в Киевской губернии. Киев, 1915. Вып. 1.298 с.

15. Устьянцев В. Кормове питання на Україні: доповідь на I сесії науковоконсультаційної ради при НКЗС 4-7 квітня 1928 р. Харків, 1928. 25 с.

16. Устьянцев В. Науково-дослідча праця в справі годування сільськогосподарських тварин. Записки Київського сільсько-господарського інституту. Т. 4. Київ, 1929. С. 120-123.

17. Устьянцев В. П., Серапин С.В. Выращивание молодняка крупного рогатого молочного скота. Выращивание молодняка крупного рогатого скота. М.: Сельхозгиз, 1934. С. 26-83.

18. Устьянцев В. П., Григоренко I.I., Серапін С. В. Досвіди з силосування бурякової гички та годівлею нею молочних корів. Київ, 1928. Вип. 12. 56 с.

19. Устьянцев В., Швабе А., Цыганов Н., Дунаев М.. Влияние добавки мела и рыбьего жира на минеральный обмен у телят. Проблемь животноводства. 1934. № 2. С. 89-96.

20. Устьянцев, В. П. Научно-исследовательская работа в области подготовки и использования кормов. Проблемы животноводства. 1934. № 1. C. $95-101$.

21. Устьянцев В.П. Подготовка к отелам и сохранение приплода. Проблемы животноводства. 1933. № 2. С. 16-19.

22. Shulha V. General physiology formation and development as a science in Ukraine in the $\mathrm{XIX}^{\text {th }}$ - during the 30 -ies of the $\mathrm{XX}^{\text {th }}$ century. Eastern European Historical Bulletin. 2020. № 16. P. 36-49. DOI: https://doi.org/10.24919/2519$\underline{058 x .16 .210908 .}$.

\section{References}

1. Bey, R. V. (2019). Development of hygiene of farm animals in Ukraine (the second half of the $19^{\text {th }}-$ early $21^{\text {th }}$ centuries). Relevant research of historical sciences: collective monograph. Lviv-Toruń: Liha-Pres. 31-48. DOI https://doi.org/10.36059/978-966-397-100-1/31-48.

2. Borodai, I. S. (2019). Formation and development of the science of farm animal feeding (the second half of the $19^{\text {th }}$ - early $21^{\text {st }}$ centuries). Relevant research of historical sciences: collective monograph. Lviv-Torun: Liha-Pres. 49-67. DOI https://doi.org/10.36059/978-966-397-100-1/49-67. 
3. Borodai, I. S. (2012). Ustjjancev Vasylj Pavlovych [Ustyantsev Vasily Pavlovich]. Istorija Instytutu rozvedennja $i$ ghenetyky tvaryn u podijakh, faktakh, bioghrafijakh uchenykh [History of the Institute of Animal Breeding and Genetics in events, facts, biographies of scientists] / nauk. red. K.V. Kopylova. Boryspil. 316317. [in Ukrainian].

4. Borodai, I. (2009). Rozvytok zootekhnichnoji nauky v Ukrajini v konteksti dijaljnosti profesora V.P. Ustjjanceva [Development of zootechnical science in Ukraine in the context of activities of Professor V.P. Ustyantsev]. Istorija ukrajinsjkoji nauky na mezhi tysjacholitj [History of Ukrainian science at the turn of the millennium]. Vol. 41.28-35 [in Ukrainian].

5. Borodai, I.S. (2012). Teoretyko-metodologhichni osnovy stanovlennja ta rozvytku vitchyznjanoji zootekhnichnoji nauky [Theoretical and methodological bases of formation and development of domestic zootechnical science] / nauk. red. V.A. Verhunov. Vinnytsia. 416. [in Ukrainian].

6. Verhunov, V.A. (2018). Istorija siljsjkoghospodarsjkoji doslidnoji spravy v Ukrajini (Do 100-richchja stvorennja Nacionaljnoji akademiji nauk Ukrajiny) [History of agricultural research in Ukraine (To the 100th anniversary of the National Academy of Sciences of Ukraine)]. (Ch. 1: Tvorci ta rozbudovnyky (bioghrafichni narysy [Creators and developers (biographical essays)]. Kyiv: Aghrarna nauka. 604. [in Ukrainian].

7. Didenko, V. V. (1998). Narys istoriji Nacionaljnogho aghrarnogho universytetu (do storichchja zasnuvannja) [Essay on the history of the National Agrarian University (to the centenary)]. Kyiv : Aghrarna nauka. 175. [in Ukrainian].

8. Zubets, M. M., \& Borodai, I. S. (2011). Kyjivsjka doslidna stancija tvarynnyctva «Terezyne»: istorija, zdobutky, vcheni [Kyiv Research Station of Animal Husbandry «Terezine»: history, achievements, scientists] / nauk. red. V.A. Verghunov. Vinnytsia. 208. [in Ukrainian].

9. Zubets, M. M. (2011). Uchenyj-doslidnyk V.P. Ustjjancev: jogho vnesok $u$ stanovlennja zootekhnichnoji nauky [Researcher V.P. Ustyantsev: his contribution to the formation of zootechnical science]. Tvarynnyctvo Ukrajiny [Animal Husbandry of Ukraine]. 4. 34-36. [in Ukrainian].

10. Kyrychok, R.I., Gholikova, O.M., \& Ghrycenko, Z.I. (2006). Kharkivsjkyj nacionaljnyj aghrarnyj universytet im. V.V. Dokuchajeva. 1816-2006 [Kharkiv National Agrarian University named after V.V. Dokuchaev]. Kharkiv. 367. [in Ukrainian].

11. Neiman, O. F., Zavadovskii, B.M., \& Azimov, G.I. (1935). Vsesoiuznyi institut zhivotnovodstva [All-Union Institute of Animal Husbandry]. Problemy zhivotnovodstva [Problems of Animal Husbandry]. 1-2, 11-20. [in Russian].

12.Osobova sprava V.P. Ustjjanceva [Personal file of V.P. Ustyantsev] // Derzhavnyj arkhiv m. Kyjiv [State Archive of Kyiv]. F. 16. Op. 465. Spr. 4820. 16 ark. [in Ukrainian].

13. Osobova sprava V.P. Ustjjanceva [Personal file of V.P. Ustyantsev] // Centraljnyj derzhavnyj arkhiv vyshhykh orghaniv vlady $i$ upravlinnja Ukrajiny [Central State Archive of the Highest Authorities and Administration of Ukraine]. F. 166. Op. 12. Spr. 7904.7 ark. [in Ukrainian]. 
14. Ustyantsev, V.P. (1915). Materialy po obsledovaniiu zhivotnovodstva v Kievskoi gubernii [Materials for the survey of animal husbandry in the Kiev province]. Ocherk polozheniia krestianskogo zhivotnovodstva $v$ Kievskoi gubernii [Essay on the situation of peasant animal husbandry in the Kiev province]. Kiev. Vyp. 1. 298. [in Russian].

15. Ustyansev, V. (1928). Kormove pytannja na Ukrajini: dopovidj na I sesiji naukovo-konsuljtacijnoji rady pry NKZS 4-7 kvitnja 1928 r. [Fodder issue in Ukraine: report at the first session of the Scientific Advisory Council at the PCLA on April 4-7, 1928]. Kharkiv. 25. [in Ukrainian].

16. Ustyansev, V. (1929). Naukovo-doslidcha pracja v spravi ghoduvannja siljsjkoghospodarsjkykh tvaryn [Research work in the field of feeding farm animals]. Zapysky Kyjivsjkogho siljsjko-ghospodarsjkogho instytutu [Notes of the Kyiv Agricultural Institute]. Kyiv. Vol. 4. 120-123. [in Ukrainian].

17. Ustyantsev, V.P., \& Serapin, S.V. (1934). Vyrashchivanie molodniaka krupnogo rogatogo molochnogo skota [Breeding of calves of dairy cattle]. Vyrashchivanie molodniaka krupnogo rogatogo skota [Breeding of calves of cattle]. Moscow: Selkhozgiz. 26-83. [in Russian].

18. Ustyansev, V. P., Ghryghorenko, I. I., \& Serapin S. V. (1928). Dosvidy z sylosuvannja burjakovoji ghychky ta ghodivleju neju molochnykh koriv [Experiments on silage of beet tops and feeding of dairy cows]. Kyiv. Vol. 12. 56. [in Ukrainian].

19. Ustyantsev, V., Shvabe, A., Tcyganov, N., \& Dunaev, M. (1934). Vliianie dobavki mela i rybego zhira na mineralnyi obmen u teliat [The effect of chalk and fish oil supplementation on calf mineral metabolism]. Problemy zhivotnovodstva [Problems of Animal Husbandry], 2, 89-96. [in Russian].

20. Ustyantsev, V. P. (1934). Nauchno-issledovatelskaia rabota v oblasti podgotovki $i$ ispolzovaniia kormov [Research work in the field of preparation and use of feed]. Problemy zhivotnovodstva [Problems of Animal Husbandry]. N 1. 95-101. [in Russian].

21. Ustyantsev, V.P. (1933). Podgotovka $k$ otelam i sokhranenie priploda [Preparation for calving and preservation of offspring]. Problemy zhivotnovodstva [Problems of Animal Husbandry]. N 2. 16-19. [in Russian].

22. Shulha, V. (2020). General physiology formation and development as a science in Ukraine in the XIX ${ }^{\text {th }}$ - during the 30-ies of the $\mathrm{XX}^{\text {th }}$ century. Eastern European Historical Bulletin. Vol. 16. 36-49. DOI: https://doi.org/10.24919/2519$\underline{058 x .16 .210908 .}$.

\section{Рецензент:}

Куйбida В.В., д.і.н., професор

Падалка С. С., д.і.н., професор

Надійшла до редакції 11.02.2021 р. 